\title{
APLIKASI PEMANTAUAN WILAYAH PERSEBARAN PASIEN PASCA REHABILITASI NARKOBA DI MALANG BERBASIS WEB
}

\author{
Afri Dwi Yulianto, Febriana Santi Wahyuni, Deddy Rudhistiar \\ Program Studi Teknik Informatika S1, Fakultas Teknologi Industri \\ Institut Teknologi Nasional Malang, Jalan Raya Karanglo km 2 Malang, Indonesia \\ Ady.xmm173@gmail.com
}

\begin{abstract}
ABSTRAK
Bahaya narkoba begitu dahsyat sehingga pemerintah harus menangani pengguna narkoba melalui rehabilitasi. Secara umum, rehabilitasi adalah proses mengembalikan kemampuan fisik dan non fisik ke perilaku sehari-hari sebelum ada factor negative yang berdampak pada kondisi fisik atau mental. Peramasalahan yang dialami oleh Badan Narkotika Nasional Kota Malang yaitu, kesulitan untuk memantau persebaran pasien pasca rehabilitasi narkoba. Badan Narkotika Nasional Kota Malang saat ini hanya memiliki data numerik tekstual, sangat sulit untuk dijadikan acuan informasi dan menentukan keputusan kebijakan pada suatu wilayah tanpa ada bentuk visual dari data tersebut. Sistem yang akan dibangun yaitu aplikasi pemantauan wilayah persebaran pasien pasca rehabilitasi narkoba menggunakan metode clustering. Sistem ini menggunakan metode $K$-means Clustering dan standar yang digunakan dalam pengelompokan data adalah atribut status kerja pasien setelah rehabilitasi narkoba. Cluster yang ditetapkan oleh Badan Narkotika Nasional Kota Malang yaitu Banyak, Sedang, Sedikit sesuai standar petunjuk teknis yang dimiliki. Berdasarkan hasil pengujian sistem error menunjukkan bahwa, perhitungan manual dengan perhitungan yang dilakukan oleh sistem menghasilkan tinggkat error sebesar $0 \%$. Berdasarkan hasil pengujian penggun dengan pertanyaan mengenai fitur aplikasi, maka jumlah persentase pemilihan sangat setuju sebesar $87,5 \%$ dan setuju sebesar $12,5 \%$.
\end{abstract}

\section{Kata Kunci: Metode K-Means Clustering, Sistem Informasi Geografis, Badan Narkotika Nasional}

\section{PENDAHULUAN}

Narkoba adalah suatu zat atau obat yang dapat mempengaruhi sistem saraf, menyebabkan perubahan kesadaran, suasana pengelihatan, menghilangkan rasa nyeri dan yang paling berbahaya adalah kecanduan atau ketergantungan pada penggunanya bahkan hingga kematian.

Bahaya narkoba sangat mengerikan membuat pemerintah harus menangani penyalahgunaan maupun pecandu narkoba dengan cara rehabilitasi. Secara umum, rehabilitasi adalah proses mengembalikan kemampuan fisik dan non fisik ke perilaku sehari-hari sebelum ada factor negative yang mempengaruhi tubuh atau kondisi fisik atau mental. Selain itu, keteraturan fungsi fisik dapat mengembalikan keterampilan sosial dan kreativitas setiap orang di lingkungan masyarakat, sehingga tidak lagi menggunakan narkoba.

Berdasarkan permasalahan yang dialami oleh Badan Narkotika Nasional Kota Malang yaitu, kesulitan untuk memantau persebaran pasien pasca rehabilitasi narkoba. Badan Narkotika Nasional Kota Malang saat ini hanya memiliki data numerik tekstual sehingga sangat sulit untuk dijadikan acuan informasi dan menentukan keputusan pada suatu wilayah tanpa ada bentuk visual dari data tersebut.

Oleh karena itu penulis bermaksud membuat aplikasi pemantauan wilayah persebaran pasien pasca rehabilitasi narkoba di Malang berbasis web. Aplikasi tersebut nantinya akan memberikan informasi suatu wilayah yang terdapat pasien pasca rehabilitasi narkoba berdasarkan kecamatan dan informasi mengenai pengelompokan tingkat penanganan tiap wilayah kecamatan di Malang, sehingga bagi pihak BNN Kota Malang dapat mengetahui wilayah yang perlu penanganan atau pencegahan terkait penyalahgunaan narkoba.

\section{TINJAUAN PUSTAKA}

\subsection{Penelitian Terdahulu}

Algoritma K-Means pada kasus ini akan digunakan untuk mengklasifikasikan kecamatan TanaLuwu berdasarkan hasil tanaman pangan. Tanah di Tana-Luwu terkenal dengan tanaman pangan, perkebunan atau budidaya sayuran. Tanaman pangan pada kecamatan Tana-Luwu meliputi padi, jagung dan ubi kayu. Secara administratif, Tana-Luwu terbagi menjadi empat kabupaten dan kota, yaitu Kabupaten Luwu di ibu kota Belopa, Kota Palopo, Kabupaten Luwu Utara ibu kota Masamba dan ibu kota Malili Kabupaten Luwu Timur. Hasilnya penelitian menunjukan dari 54 kecamatan di Tana-Luwu, 6 kecamatan berada pada kelompok produktif dan 48 kecamatan berada pada kelompok kurang produktif [2].

Penyakit diare sudah membunuh seperempat nyawa dari 130.000 kematian pertahun diantaranya balita, terutama pada musim peralihan, yang hampir terjadi di seluruh wilayah Indonesia, terutama di Kabupaten Langkat, Sumatera Utara. Algoritma $K$ means Clustering merupakan algoritma untuk pengelompokan data yang sama dan data yang berbeda dalam kelompok lain. Hasil Clustering wilayah sebaran mengambil cluster kecamatan Batang 
Serangan, Brandan Barat dan Permata Jaya sebagai cluster pertama pusat penularan diare serta kecamatan Hinai dan Sei Bingai sebagai cluster kedua [3].

Penerapan algoritma clustering dalam pengelompokan jumlah desa / kelurahan berdasarkan upaya antisipasi / mitigasi bencana alam. Mengurangi dampak bencana pada manusia dan harta benda. Persiapan penanggulangan bencana alam mencangkup semua kegiatan yang dilakukan sebelum ditemukannya tanda-tanda bencana untuk mendorong pemanfaatan sumber daya alam yang tersedia, mulai dari tingkat komunikasi local hingga penanganan bencana alam. Data tersebut akan diolah dengan clustering menjadi 3 cluster yaitu cluster antisipasi tinggi, cluster antisipasi sedang dan antisipasi rendah [4].

Indonesia merupakan negara yang terdiri dari pulau-pulau dan banyak wilayah terpencil yang belum terjangkau. Ketersediaan sarana penunjang kesehatan yang kurang memadai sehingga sulit menanggulangi pencegahan penyakit di daerah tersebut. Sistem informasi geografis digunakan untuk menandai area untuk menentukan penyebaran penyakit. Dengan menggunakan fasilitas kesehatan yang ada, dimungkinkan untuk menampilkan data penyakit dalam sistem informasi dan mengidentifikasi daerah yang tidak memiliki fasilitas kesehatan yang memadai. SIG memperoleh data tentang penyebaran penyakit, yang dapat membantu institusi medis untuk mengidentifikasi penyebaran penyakit dan mendapatkan kontrol medis dari pihak terkait. [7].

Kota Bandung merupakan salah satu kota terbesar di Indonesia. Peningkatan jumlah penduduk Kota Bandung dari tahun ke tahun membuktikan hal ini. Hal ini menyebabkan bertambahnya jumlah penduduk Kota Bandung, menjadikan Kota Bandung semakin padat penduduknya dan semakin padat penduduknya. Untuk membantu pemerintah dalam menghindari penumpukan penduduk di satu wilayah maka diperlukan clustering jumlah penduduk di setiap kecamatan di Kota Bandung. Oleh karena itu, dilakukan clustering kepada 30 kecamatan di Kota Bandung dengan algoritma K-Means clustering. Tahap penelitian dilakukan dengan mengumpulkan data sebanyak 30 kecamatan di Kota Bandung, kemudian dilakukan normalisasi data menggunakan min-max normalization, Setelah normalisasi, langkah selanjutnya adalah menggunakan metode $K$-means untuk mengelompokkan data, dan langkah terakhir adalah meringkas hasil penelitian. [8].

\subsection{Narkoba}

Menurut terminologi kedokteran, Narkoba adalah obat yang dapat menghilangkan rasa sakit dan nyeri pada khususnya, yang dapat disebabkan dari daerah vitreous atau rongga dada, rongga perut, dan juga dapat menyebabkan efek stupor atau hilang kesadaran dalam jangka waktu yang lama serta dapat menyebabkan kecanduan [1]. Narkotika adalah obat atau zat yang dapat menenangkan syaraf, menimbulkan ketidaksadaran atau pembiusan, menghilangkan rasa sakit dan nyeri, menimbulkan kantuk atau iritasi, dapat menyebabkan pingsan dan dapat menyebabkan kecanduan, yang ditetapkan oleh Menteri Kesehatan sebagai narkotika [5].

\subsection{Rehabilitasi}

Rehabilitasi merupakan proses penyembuhan pengguna narkoba. Proses rehabilitasi tidak hanya bagi pengguna narkoba yang tertangkap oleh kepolisian, tetapi juga bagi pengguna yang ingin sembuh dari ketergantungan narkoba karena kesadarannya sendiri.

Rehabilitasi narkoba dibagi menjadi dua kategori, yaitu rehabilitasi medik dan rehabilitasi sosial. Rehabilitasi medik merupakan proses kegiatan pengobatan komprehensif yang membebaskan pengguna napza dari ketergantungan napza. Rehabilitasi medik dilaksanakan di rumah sakit yang ditunjuk oleh Menteri Kesehatan, lembaga rehabilitasi yang diselenggarakan oleh instansi pemerintah dan lembaga rehabilitasi yang diselenggarakan oleh dinas kemasyarakatan. Rehabilitasi sosial merupakan suatu proses kegiatan rehabilitasi yang menyeluruh secara fisik, psikis dan sosial agar mantan pecandu narkoba dapat kembali menjalankan fungsi sosialnya dalam kehidupan masyarakat [9].

\subsection{Sistem Informasi Geografi}

Sistem Informasi Geografis (SIG) adalah sistem atau teknologi berbasis komputer yang dirancang untuk mengumpulkan, menyimpan, mengolah, menganalisis, dan menyajikan informasi, data, dan objek atau fenomena yang berkaitan dengan lokasi atau keberadaannya di permukaan bumi. Pada dasarnya SIG dapat dibedakan menjadi beberapa subsistem yang terkait, antara lain input data, pengelolaan data, pengolahan atau analisis data, laporan dan hasil analisis. Dalam proses pembangunan, diperlukan informasi tentang sumber daya alam dan lokasinya [6].

\subsection{Clustering}

Analisis clustering adalah proses membagi data dalam kumpulan menjadi beberapa kelompok, kesamaan data dalam satu kelompok lebih besar dari pada kesamaan data pada kelompok lain. Potensi clustering adalah dapat digunakan untuk menentukan struktur pada data, yang selanjutnya dapat digunakan dalam berbagai aplikasi, seperti klasifikasi, pengolahan citra dan pengenalan pola [10].

\subsection{Metode K-Means}

K-means adalah metode pengelompokan data non-hierarki, yang mencoba membagi data yang ada menjadi satu atau lebih cluster / grup. Metode ini membagi data menjadi cluster / kelompok sehingga data dengan karakteristik yang sama dikelompokkan 
ke dalam cluster yang sama, dan data yang memiliki karakteristik berbeda dikelompokkan ke dalam kelompok lainnya [10]. Algoritma untuk melakukan clustering $K$-means adalah sebagai berikut :

1. Menentukan banyaknya $\mathrm{k}$ cluster yang diinginkan.

2. Secara acak menentukan pusat cluster awal (centroid) berdasarkan $\mathrm{k}$ data objek.

3. Menentukan jarak terdekat dari masing-masing objek pengamatan ke pusat centroid sebagai berikut yang telah ditentukan menggunakan jarak Euclidean :

$$
d(x, y)=\sqrt{\left(x_{1}-y_{1}\right)^{2}+\left(x_{2}-y_{2}\right)^{2}+\ldots+\left(x_{m}-y_{m}\right)^{2}}
$$

Dimana :

$\mathrm{d}(\mathrm{x}, \mathrm{y})$ adalah jumlah dimensi (atribut)

(x) adalah titik koordinat object dan

(y) adalah titik koordinat centroid.

4. Menentukan jarak terdekat objek dengan centroid.

5. Menentukan pusat cluster baru (centroid) dengan menghitung rata-rata setiap cluster dengan rumus sebagai berikut :

$$
c_{k l}=\frac{x_{1 l}+x_{2 l}+\cdots+x_{p l}}{p}
$$

Dimana :

$C_{k l}$ : Nilai centroid ke-k pada variabel ke-l

$p$ : Banyak jumlah data

6. Jika objek masih memiliki data yang berubah cluster atau nilai centroid berubah, maka ulangi langkah ke-3. Jika tidak ada, maka hentikan proses clustering [2].

\section{METODE PENELITIAN}

\subsection{Analisis Sistem}

Sistem yang dirancang pada aplikasi pemantauan wilayah persebaran pasien pasca rehabilitasi narkoba di Malang berbasis web ini merupakan sistem untuk menginformasikan pengelompokan wilayah pasien pasca rehabilitasi narkoba di Malang. Dalam sistem ini, metode K-means Clustering digunakan untuk mengelompokkan wilayah perkecamata. Cluster yang ditetapkan yaitu banyak, sedang dan sedikit sesuai petunjuk teknis dari Badan Narkotika Nasional Kota Malang.

\subsection{Blok Diagram Sistem}

Dalam sistem pemantauan wilayah persebaran pasien pasca rehabilitasi narkoba di Malang, dilakukan pemetaan wilayah dengan tingkat kerawanan berdasarkan Kecamatan di Malang, terlihat pada Gamabar 1:

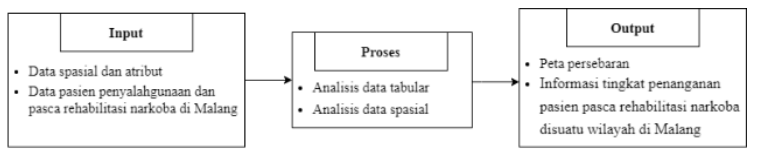

Gambar 1. Desain Arsitektur Sistem

Berdasarkan desain arsitektur sistem pada Gambar 3.1 diatas terdapat input, proses dan output, berikut adalah penjelasan mengenai desain tersebut :

1. Input

a. Data spasial dan data atribut

Data spasial merupakan gambaran wilayah yang terdapat di permukaan bumi. Sedangkan data atribut merupakan data yang memuat informasi yang dimiliki oleh objek pada data spasial.

b. Data seleruh kecamatan dan kelurahan yang ada di Malang.

c. Data pasien pasca rehabilitasi.

2. Proses

a. Analisis data tabular yaitu menganalisa data dalam bentuk tabel.

b. Analisis data spasial yaiut menganalisis data untuk dibuat menjadi peta.

3. Output

a. Peta perseberan wilayah Malang.

b. Informasi tingkat penanganan pasien pasca rehabilitasi narkoba pada wilayah di Malang.

\subsection{Flowchart Sistem}

Flowchart Sistem menunjukkan alur kerja atau proses urutan sistem dari awal berjalanya sistem hingga berakhir, alur ini hanya menggambarkan langkah-langkah umum dari awal mula hingga akhir proses yang dilakukan. Flowchart sistem dapat dilihat pada Gambar 2. 


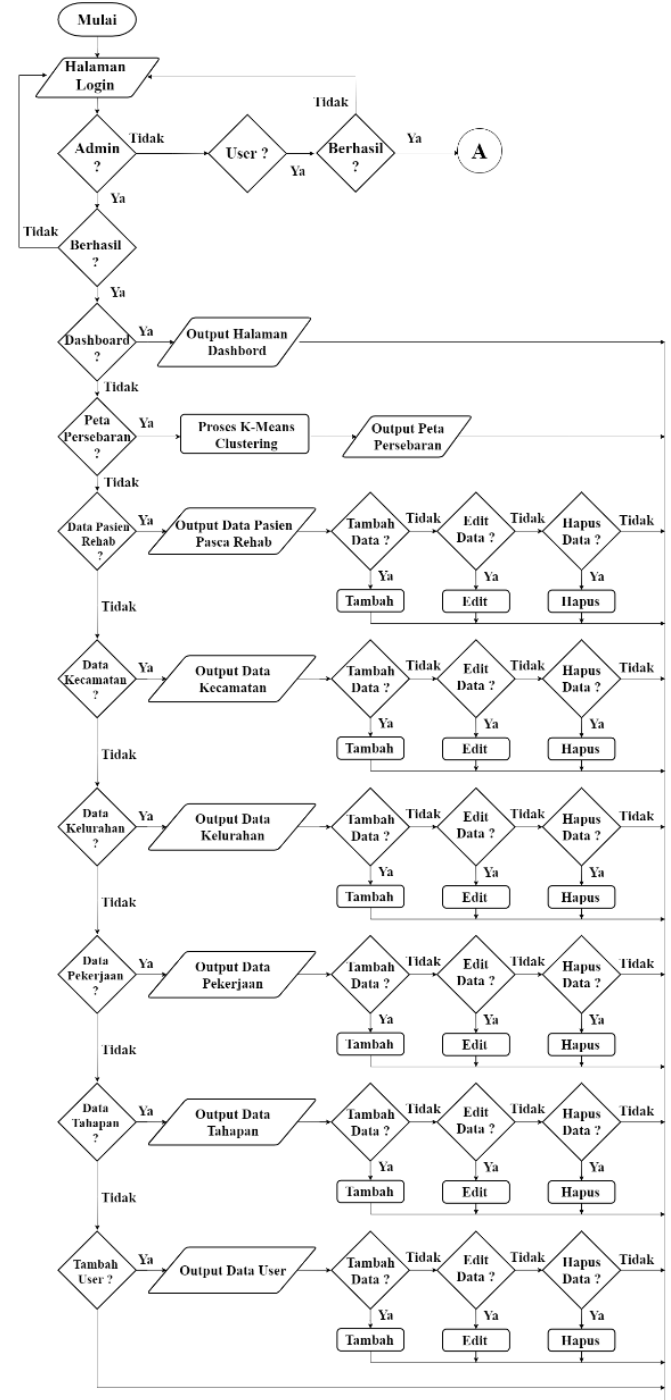

(A)

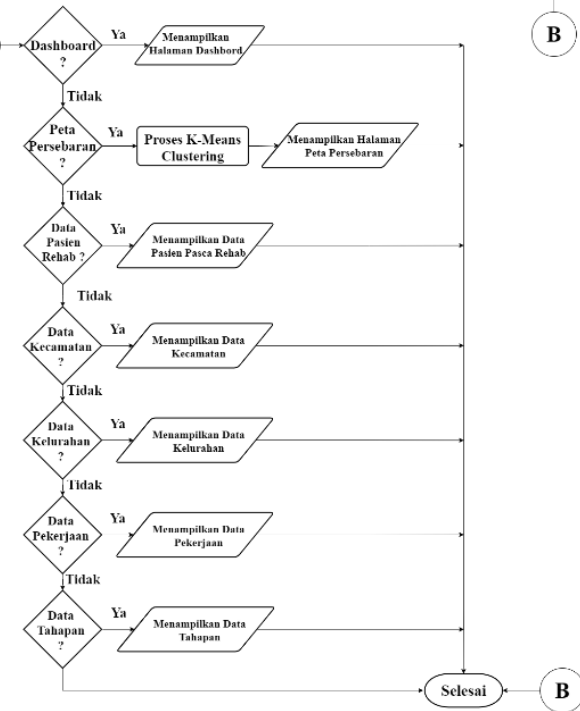

Gambar 2 Flowchart Sistem

Pada gambar 2 Flowchart Sistem dimulai dari halaman login sebagai administrator, setelah login akan ditampilkan menu halaman dashboard yang berisi informasi tentang pasien pasca rehabilitasi. Terdapat beberapa menu yaitu peta persebaran yang sudah diproses dengan menggunakan metode $K$-means Clustering. Terdapat juga menu informasi dara pasien selesai rehab, data kecamatan, data kelurahan, data pekerjaan, data tahapan dan data user. Admin dapat menambahkan, merubah dan menghapus data. Sedangkan login sebagai user, hanya bisa menampilkan informasi dashboard, peta persebaran, data pasien rehabilitasi, data kecamatan dan kelurahan, data pekerjaan dan data tahapan.

\subsection{Flowchart Metode K-Means}

Flowchart metode ini menjelaskan tentang proses urutan metode k-menas clustering. Seperti ditunjukkan pada gambar 3 .

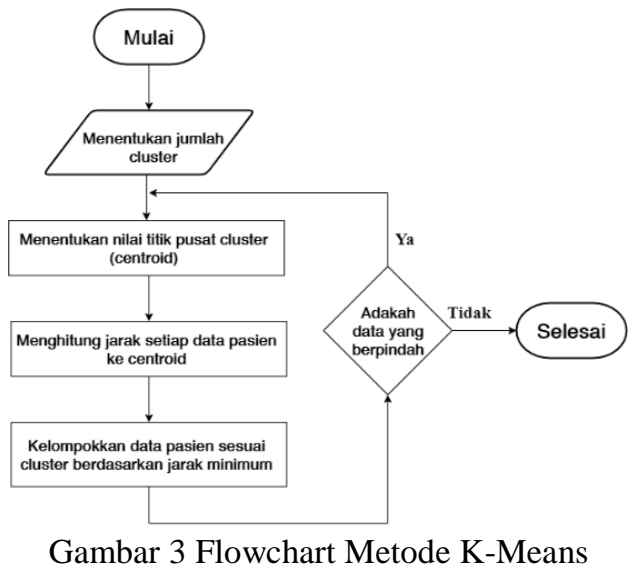

Pada Gambar 3 Flowchart menjelaskan proses metode K-means, mulai dari menentukan jumlah cluster, setelah menentukan jumlah cluster, kemudian menentukan nilai titik pusat atau centroid, setelah menemukan centroid, masuk ke proses pernghitungan jarak masing-masing data pada centroid. Kemudian kelompokkan datanya menurut cluster sesuai jarak minimum. Proses iterasi pertama selesai, lalu kembali ke tahap ketiga untuk melanjutkan proses iterasi berikutnya. Setelah centroid baru didapat, proses kembali ke tahap menghitung jarak tiap data pada centroid menggunakan centroid baru. Jika data pada iterasi sebelumnya sama atau tidak ada transfer data sama sekali maka proses akan terhenti. Jika proses dihentikan, akan diperoleh hasil clustering data wilayah sesuai dengan tingkat penanganan pasien pasca rehabilitasi.

\section{HASIL DAN PEMBAHASAN}

\subsection{Pengujian}

Dalam pengujian Metode k-means clustering penulis mengambil data pasien pasca rehabilitasi narkoba yang terjadi pada tahun 2018-2019 pada BNN Kota malang. 


\subsection{Pengelompokan Hasil Clustering}

Berikut adalah langkah perhitungan metode $K$ means Clusterung dengan data yang di peroleh dari BNN Kota Malang.

Tabel 1. Data kasus narkoba

\begin{tabular}{|l|l|c|c|}
\hline No & Kecamatan & Pelajar & Pekerja \\
\hline 1 & Lowokwaru & 84 & 3 \\
\hline 2 & Blimbing & 63 & 5 \\
\hline 3 & Sukun & 270 & 7 \\
\hline 4 & Kedungkandang & 49 & 1 \\
\hline 5 & Klojen & 79 & 3 \\
\hline 6 & Pakis & 10 & 0 \\
\hline 7 & Karangploso & 8 & 0 \\
\hline 8 & Singosari & 8 & 1 \\
\hline 9 & Dau & 15 & 1 \\
\hline 10 & Wonosari & 1 & 0 \\
\hline 11 & Turen & 1 & 0 \\
\hline 12 & Wagir & 68 & 0 \\
\hline 13 & Tajinan & 1 & 0 \\
\hline 14 & Pakisaji & 21 & 1 \\
\hline 15 & Gondanglegi & 1 & 0 \\
\hline 16 & Pagelaran & 1 & 0 \\
\hline 17 & Lawang & 1 & 1 \\
\hline 18 & Bululawang & 2 & 1 \\
\hline \multicolumn{2}{|l}{} \\
\end{tabular}

Selanjutnya menentukan centroid awal terlebih dahulu, penulis mengambil kasus menggunakan 3 centroid yaitu $\mathrm{C} 1$ mengambil nilai tertinggi, $\mathrm{C} 2$ mengambil nilai rata-rata dan $\mathrm{C} 3$ mengambil nilai terendah.

Tabel 2. Centroid awal
\begin{tabular}{|l|c|c|}
\hline & A & B \\
\hline C1 & 270 & 7 \\
\hline C2 & 37.94444 & 1.333333 \\
\hline C 3 & 1 & 0 \\
\hline
\end{tabular}

Setelah nilai centroid awal sudah di tetapkan, langkah selanjutnya adalah menggunakan perhitungan jarak Euclidien menggunakan persamaan (2.1) untuk menghitung jarak masing-masing data pada ketiga centroid. Hasil iterasi-1 ditunjukkan pada Tabel 3

Tabel 3. Jarak Euclidien dari hasil Iterasi ke-1

\begin{tabular}{|l|c|c|c|c|}
\hline Kecamatan & D(p,c1) & D(p,c2) & D(p,c3) & Cluster \\
\hline Lowokwaru & 186.043 & 46.0857 & 83.0542 & 2 \\
\hline Blimbing & 207.0097 & 25.32243 & 62.20129 & 2 \\
\hline Sukun & 0 & 232.1247 & 269.0911 & 1 \\
\hline Kedungkandang & 221.0814 & 11.06058 & 48.01042 & 2 \\
\hline Klojen & 191.0419 & 41.08937 & 78.05767 & 2 \\
\hline Pakis & 260.0942 & 27.97624 & 9 & 3 \\
\hline Karangploso & 262.0935 & 29.97411 & 7 & 3 \\
\hline Singosari & 262.0687 & 29.9463 & 7.071068 & 3 \\
\hline Dau & 255.0706 & 22.94687 & 14.03567 & 3 \\
\hline Wonosari & 269.0911 & 36.9685 & 0 & 3 \\
\hline Turen & 269.0911 & 36.9685 & 0 & 3 \\
\hline Wagir & 202.1213 & 30.08512 & 67 & 2 \\
\hline Tajinan & 269.0911 & 36.9685 & 0 & 3 \\
\hline Pakisaji & 249.0723 & 16.94772 & 20.02498 & 2 \\
\hline Gondanglegi & 269.0911 & 36.9685 & 0 & 3 \\
\hline Pagelaran & 269.0911 & 36.9685 & 0 & 3 \\
\hline
\end{tabular}

\begin{tabular}{|l|c|c|c|c|}
\hline Lawang & 269.0669 & 36.94595 & 1 & 3 \\
\hline Bululawang & 268.0672 & 46.0857 & 1.414214 & 3 \\
\hline
\end{tabular}

Selanjutnya, seperti sebelumnya, hitung jarak setiap data dari tiga centroid. Jika keanggotaan data telah berubah, maka harus diulangi lagi hingga data untuk setiap cluster tidak berubah. Pada iterasi-3, hasilnya tidak berubah, sehingga iterasi berhenti.

\subsection{Hasil pembentukan Cluster}

Hasil proses clustering sampai iterasi kedua, karena nilai dan cluster tidak berubah. Jumlah dari cluster 1 (berat) berjumlah 1 , cluster 2 (ringan) berjumlah 6 dan cluster 3 (ringan) berjumlah 11 .

Tabel 4. Hasil clustering

\begin{tabular}{|l|c|c|c|}
\hline Kecamatan & C1(Berat) & C2(Sedang) & C3(Ringan) \\
\hline Lowokwaru & & $\checkmark$ & \\
\hline Blimbing & & $\checkmark$ & \\
\hline Sukun & $\checkmark$ & & \\
\hline Kedungkandang & & $\checkmark$ & \\
\hline Klojen & & $\checkmark$ & \\
\hline Pakis & & & $\checkmark$ \\
\hline Karangploso & & & $\checkmark$ \\
\hline Singosari & & & $\checkmark$ \\
\hline Dau & & & $\checkmark$ \\
\hline Wonosari & & & $\checkmark$ \\
\hline Turen & & & $\checkmark$ \\
\hline Wagir & & $\checkmark$ & \\
\hline Tajinan & & & $\checkmark$ \\
\hline Pakisaji & & & $\checkmark$ \\
\hline Gondanglegi & & & $\checkmark$ \\
\hline Pagelaran & & & $\checkmark$ \\
\hline Lawang & & & $\checkmark$ \\
\hline Bululawang & & & $\checkmark$ \\
\hline
\end{tabular}

\subsection{Pengujian Nilai Sistem Error}

Pengujian Nilai sistem error dilakukan dengan membandingkan cluster secara manual yang menerapkan metode K-means Clustering. Pengujian ini menggunakan data sebanyak 18 kecamatan. Data ini didapatkan dari BNN Kota Malang yang dikelompokkan menjadi 3 cluster yaitu Banya, Sedang dan sedikit. Pengujian secara manual dan sistem ditunjukkan pada tabel 5 .

Tabel 5. Hasil pengujian error

\begin{tabular}{|l|c|c|c|}
\hline \multicolumn{1}{|c|}{ Kecamatan } & Sistem & Manual & Error \\
\hline Lowokwaru & 279.66403 & 279.66403 & $0 \%$ \\
\hline Blimbing & 270.53391 & 270.53391 & $0 \%$ \\
\hline Sukun & 465.70121 & 465.70121 & $0 \%$ \\
\hline Kedungkandang & 283.90198 & 283.90198 & $0 \%$ \\
\hline Klojen & 274.67143 & 274.67143 & $0 \%$ \\
\hline Pakis & 322.93079 & 322.93079 & $0 \%$ \\
\hline Karangploso & 324.94737 & 324.94737 & $0 \%$ \\
\hline Singosari & 324.92868 & 324.92868 & $0 \%$ \\
\hline Dau & 317.87407 & 317.87407 & $0 \%$ \\
\hline Wonosari & 341.58491 & 341.58491 & $0 \%$ \\
\hline Turen & 341.58491 & 341.58491 & $0 \%$ \\
\hline Wagir & 266.76318 & 266.76318 & $0 \%$ \\
\hline Tajinan & 341.58491 & 341.58491 & $0 \%$ \\
\hline
\end{tabular}




\begin{tabular}{|l|c|c|c|}
\hline Pakisaji & 311.87074 & 311.87074 & $0 \%$ \\
\hline Gondanglegi & 341.58491 & 341.58491 & $0 \%$ \\
\hline Pagelaran & 341.58491 & 341.58491 & $0 \%$ \\
\hline Lawang & 341.58491 & 341.58491 & $0 \%$ \\
\hline Bululawang & 338.55933 & 338.55933 & $0 \%$ \\
\hline
\end{tabular}

Berdasarkan pengujian data diatas, maka persentase pengujiannya dengan rumus sebagai berikut :

$$
\frac{\text { perhitungan sistem - perhitungan manual }}{\text { perhitungan manual }} \times
$$

Maka dapat disimpulkan hasil yang ditunjukkan dari pengujian sistem error dari 18 kecamatan tingkat error adalah 0\% secara garis besar program berjalan 100\% sesusai dengan perhitungan tanpa adanya error.

\subsection{Hasil Tampilan Halaman Login}

Tampilan halaman login sebelum mengakses aplikasi pemantauan wilayah persebaran pasien pasca rehabilitasi narkoba di Malang berbasis web. Tampilan seperti pada Gambar 4.

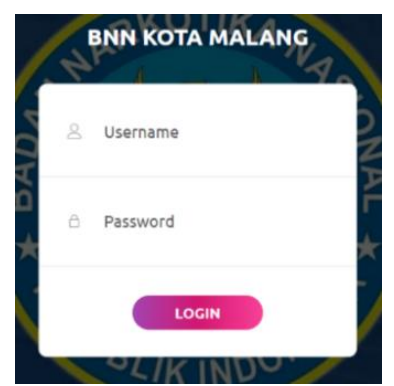

Gambar 4. Tampilan halaman login

\subsection{Halaman Dashboard}

Halaman dashboard berisi informasi tentang jumlah data pasien pasca rehabilitasi, jumlah user, jumlah kecamatan dan kelurahan di Malang. Terdapat juga grafik clustering dari peta persebaran, grafik jumlah pasien pasca rehabilitasi berdasarkan jenis kelamin, grafik berdasarkan usia pasien pasca rehabilitasi dan grafik berdasarkan pekerjaan pasien pasca rehabilitasi. Seperti yang ditunjukkan pada Gambar 5

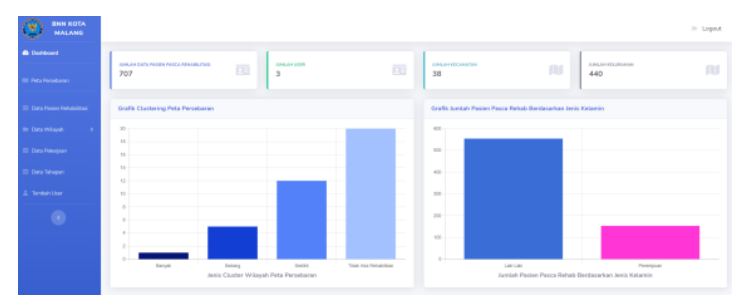

Gambar 5. Tampilan halaman dashboard

\subsection{Halaman Peta Persebaran}

Halaman peta persebaran berisi wilayah yang sudah melalui proses clustering. Wilayah yang sudah melalui clustering dikelompokan yaitu banyak,

sedang, sedikit dan tidak ada kasus. Seperti yang ditunjukkan pada Gambar 6

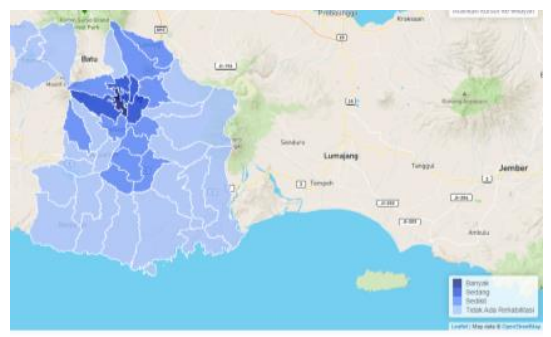

Gambar 6. Halaman peta persebaran

\subsection{Halaman Data Pasien Pasca Rehabilitasi}

Halaman data pasien pasca rehabilitasi, di mana administrator dapat melihat, menambah, mengubah dan menghapus data pasien. Seperti yang ditunjukkan pada Gambar 7

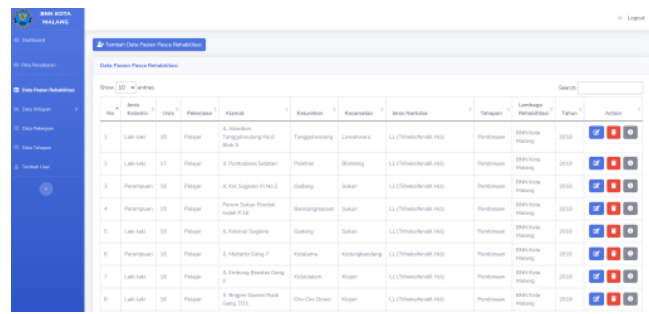

Gambar 7. Halaman data pasien pasca rehabilitasi

\subsection{Halaman Data Wilayah Kecamatan}

Halaman data wilayah kecamatan dimana administrator dapat melihat, menambah, mengubah dan menghapus data kecamatan. Seperti yang ditunjukkan pada Gambar 8

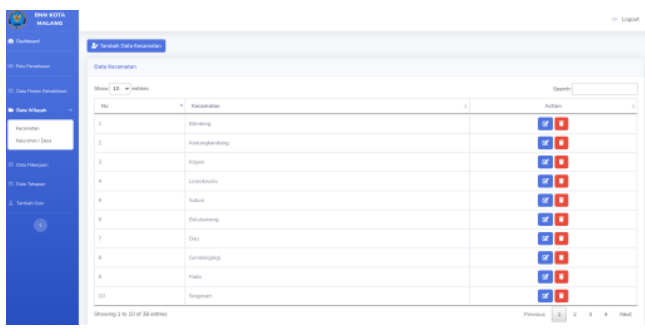

Gambar 8. Halaman data kecamatan

\subsection{Halaman Data Wilayah Kelurahan}

Halaman data wilayah kelurahan dimana administrator dapat melihat, menambah, mengubah dan menghapus data kelurahan. Seperti yang ditunjukkan pada Gambar 9

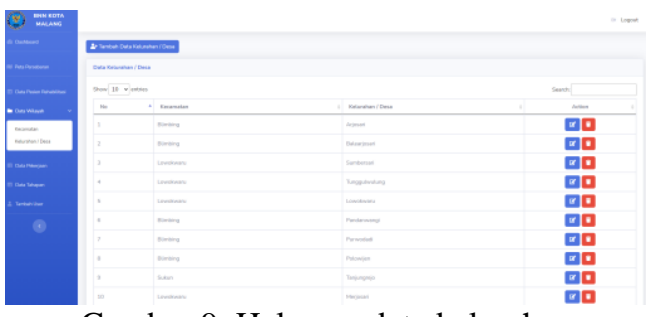

Gambar 9. Halaman data kelurahan 


\subsection{Halaman Data Wilayah Pekerjaan}

Halaman data pekerjaan, di mana administrator dapat melihat, menambah, mengubah dan menghapus data pekerjaan. Seperti yang ditunjukkan pada Gambar 10

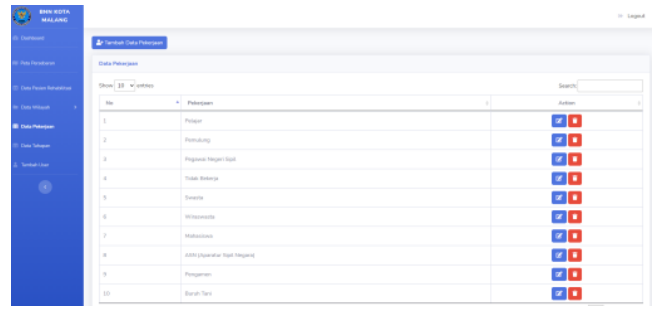

Gambar 10 Halaman data pekerjaan

\subsection{Halaman Data Wilayah Tahapan}

Halaman data tahapan, administrator dapat melihat, menambah, mengubah dan menghapus data tahapan. Seperti yang ditunjukkan pada Gambar 11

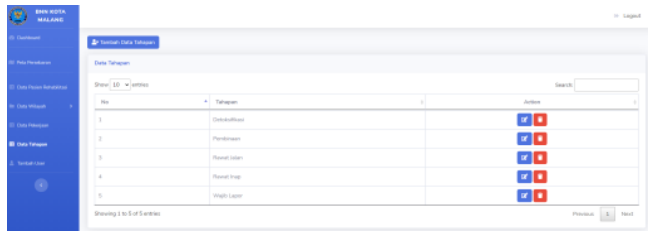

Gambar 11 Halaman data tahapan

\subsection{Pengujian Sistem dengan Black box}

Dalam pengujian ini, karakteristik fungsional dari program atau mode kerja aplikasi akan diuji. Pengujian adalah proses menampilkan sistem bertujuan untuk menemukan kesalahan atau tidak pada aplikasi. Hasil pengujian sistem menggunakan metode black box ditunjukkan pada Tabel 6 .

Tabel 6. Pengujian sistem dengan black box

\begin{tabular}{|c|c|c|c|c|}
\hline No & Pengujian & Nama Event & $\begin{array}{c}\text { Hasil Yang } \\
\text { Diharapkan }\end{array}$ & $\begin{array}{l}\text { Kesim } \\
\text { pulan }\end{array}$ \\
\hline 1 & $\begin{array}{l}\text { Halaman } \\
\text { login }\end{array}$ & $\begin{array}{l}\text { Klik button } \\
\text { login }\end{array}$ & $\begin{array}{l}\text { Tampil halaman } \\
\text { dashboard }\end{array}$ & Berhasil \\
\hline 2 & $\begin{array}{l}\text { peta } \\
\text { persebaran }\end{array}$ & $\begin{array}{l}\text { Klik menu peta } \\
\text { persebaran }\end{array}$ & $\begin{array}{l}\text { Tampil peta } \\
\text { persebaran }\end{array}$ & Berhasil \\
\hline 3 & $\begin{array}{l}\text { Halaman } \\
\text { data } \\
\text { pecandu }\end{array}$ & $\begin{array}{l}\text { Klik menu data } \\
\text { pecandu } \\
\text { tambah, edit } \\
\text { dan hapus }\end{array}$ & $\begin{array}{l}\text { Tampil informasi, } \\
\text { tambah, edit, dan } \\
\text { hapus data }\end{array}$ & Berhasil \\
\hline 4 & $\begin{array}{l}\text { Halaman } \\
\text { data pasien } \\
\text { pasca } \\
\text { rehab }\end{array}$ & $\begin{array}{l}\text { Klik menu data } \\
\text { pasien pasca } \\
\text { rehab tambah, } \\
\text { edit dan hapus }\end{array}$ & $\begin{array}{l}\text { Tampil informasi, } \\
\text { tambah, edit, dan } \\
\text { hapus data }\end{array}$ & Berhasil \\
\hline 5 & $\begin{array}{l}\text { Halaman } \\
\text { data } \\
\text { kecamatan }\end{array}$ & $\begin{array}{l}\text { Klik menu data } \\
\text { kecamatan } \\
\text { tambah, edit } \\
\text { dan hapus } \\
\end{array}$ & $\begin{array}{l}\text { Tampil informasi, } \\
\text { tambah, edit, dan } \\
\text { hapus data }\end{array}$ & Berhasil \\
\hline 6 & $\begin{array}{l}\text { Halaman } \\
\text { data } \\
\text { kelurahan }\end{array}$ & $\begin{array}{l}\text { Klik menu data } \\
\text { kelurahan } \\
\text { tambah, edit } \\
\text { dan hapus }\end{array}$ & $\begin{array}{l}\text { Tampil informasi, } \\
\text { tambah, edit, dan } \\
\text { hapus data }\end{array}$ & Berhasil \\
\hline 7 & $\begin{array}{l}\text { Halaman } \\
\text { data } \\
\text { pekerjaan }\end{array}$ & $\begin{array}{l}\text { Klik menu data } \\
\text { pekerjaan } \\
\text { tambah, edit } \\
\text { dan hapus }\end{array}$ & $\begin{array}{l}\text { Tampil informasi, } \\
\text { tambah, edit, dan } \\
\text { hapus data }\end{array}$ & Berhasil \\
\hline
\end{tabular}

\begin{tabular}{|c|l|l|l|l|}
\hline No & Pengujian & Nama Event & \multicolumn{1}{|c|}{$\begin{array}{c}\text { Hasil Yang } \\
\text { Diharapkan }\end{array}$} & $\begin{array}{c}\text { Kesim } \\
\text { pulan }\end{array}$ \\
\hline 8 & $\begin{array}{l}\text { Halaman } \\
\text { data } \\
\text { tahapan }\end{array}$ & $\begin{array}{l}\text { Klik menu data } \\
\text { tahapan } \\
\text { tambah, edit } \\
\text { dan hapus }\end{array}$ & $\begin{array}{l}\text { Tampil informasi, } \\
\text { tambah, edit, dan } \\
\text { hapus data }\end{array}$ & Berhasil \\
\hline
\end{tabular}

Maka dapat disimpulkan bahwa dari pengujian black box, sistem berjalan sesuai yang diharpkan tanpa adanya kesalahan pada setiap menu aplikasi yang dibuat.

\subsection{Pengujian Fungsional Pengguna}

Pengujian dilakukan pada pengguna terhadap aplikasi pemantauan wilayah persebaran pasien pasca rehabilitasi narkoba di malang berbasis web, pengujian dilakukan dengan memberi pertanyaan kepada para pengguna aplikasi. Hasil pengujian pengguna ditunjukkan pada Tabel 7.

Tabel 7. Hasil pengujian pengguna

\begin{tabular}{|l|l|c|c|c|c|}
\hline \multirow{2}{*}{ No } & \multicolumn{1}{|c|}{ Pertanyaan } & \multicolumn{4}{|c|}{ Hasil Uji } \\
\cline { 3 - 5 } & \multicolumn{1}{|c|}{ SS } & S & KS & TS \\
\hline 1 & $\begin{array}{l}\text { Apakah aplikasi } \\
\text { pemantauan wilayah } \\
\text { persebaran pasien pasca } \\
\text { rehabilitasi narkoba } \\
\text { mudah digunakan? }\end{array}$ & 1 & 1 & 0 & 0 \\
\hline 2 & $\begin{array}{l}\text { Apakah fitur dari } \\
\text { aplikasi ini mudah } \\
\text { dipahami ? }\end{array}$ & 2 & 0 & 0 & 0 \\
\hline 3 & $\begin{array}{l}\text { Apakah informasi } \\
\text { pasien rehabilitasi pada } \\
\text { halaman maps mudah } \\
\text { dipahami ? }\end{array}$ & 2 & 0 & 0 & 0 \\
\hline 4 & $\begin{array}{l}\text { Apakah warna tombol, } \\
\text { jenis font dan warna } \\
\text { font terlihat jelas dan } \\
\text { sesuai ? }\end{array}$ & 2 & 0 & 0 & 0 \\
\hline Jumlah & 7 & 1 & 0 & 0 \\
\hline Total Respon & & & & \\
\hline
\end{tabular}

Maka dapat disimpulkan bahwa dari pengujian pengguna dengan pertanyaan mengenai fitur aplikasi, jumlah pemilihan terhadap sangat setuju sebanyak 7 , setuju sebanyak 1, kurang setuju sebanyak 0 dan tidak setuju sebanyak 0 . Jika dipresentasekan pemilihan sangat setuju sebesar $87,5 \%$ dan setuju sebesar $12,5 \%$.

\subsection{Pengujian Fungsional Sistem}

Dalam pengujian fungsi sistem ini adalah proses untuk menemukan apakah ada kesalahan dalam sistem sebelum dipublikasikan. Hasil pengujian sistem ditunjukkan pada Tabel 8.

Tabel 8. Pengujian fungsional sistem

\begin{tabular}{|c|l|c|c|c|}
\hline \multirow{2}{*}{ No } & \multirow{2}{*}{$\begin{array}{c}\text { Item Yang Di } \\
\text { Uji }\end{array}$} & $\begin{array}{c}\text { Microsoft } \\
\text { Edge } \\
\text { (v.87.0.6) }\end{array}$ & $\begin{array}{c}\text { Google } \\
\text { Chrome } \\
\text { (v.87.0.4) }\end{array}$ & $\begin{array}{c}\text { Firefox } \\
\text { Browser } \\
\text { (v.80.0.1) }\end{array}$ \\
\hline 1 & Halaman login & $\checkmark$ & $\checkmark$ & $\checkmark$ \\
\hline 2 & $\begin{array}{l}\text { Halaman peta } \\
\text { persebaran }\end{array}$ & $\checkmark$ & $\checkmark$ & $\checkmark$ \\
\hline 3 & $\begin{array}{l}\text { Halaman data } \\
\text { pecandu }\end{array}$ & $\checkmark$ & $\checkmark$ & $\checkmark$ \\
\hline
\end{tabular}




\begin{tabular}{|c|l|c|c|c|}
\hline \multirow{2}{*}{ No } & \multicolumn{1}{|c|}{$\begin{array}{c}\text { Item Yang Di } \\
\text { Uji }\end{array}$} & $\begin{array}{c}\text { Microsoft } \\
\text { Edge } \\
\text { (v.87.0.6) }\end{array}$ & $\begin{array}{c}\text { Google } \\
\text { Chrome } \\
\text { (v.87.0.4) }\end{array}$ & $\begin{array}{c}\text { Firefox } \\
\text { Browser } \\
\text { (v.80.0.1) }\end{array}$ \\
\hline 4 & $\begin{array}{l}\text { Halaman data } \\
\text { pasien pasca } \\
\text { rehab }\end{array}$ & $\checkmark$ & $\checkmark$ & $\checkmark$ \\
\hline 5 & $\begin{array}{l}\text { Halaman data } \\
\text { kecamatan }\end{array}$ & $\checkmark$ & $\checkmark$ & $\checkmark$ \\
\hline 6 & $\begin{array}{l}\text { Halaman data } \\
\text { kelurahan }\end{array}$ & $\checkmark$ & $\checkmark$ & $\checkmark$ \\
\hline 7 & $\begin{array}{l}\text { Halaman data } \\
\text { pekerjaan }\end{array}$ & $\checkmark$ & $\checkmark$ & $\checkmark$ \\
\hline 8 & $\begin{array}{l}\text { Halaman data } \\
\text { tahapan }\end{array}$ & $\checkmark$ & $\checkmark$ & $\checkmark$ \\
\hline 9 & Logout & $\checkmark$ & $\checkmark$ & $\checkmark$ \\
\hline
\end{tabular}

penelitian selanjutnya diharapkan dapat menggunakan data per kelurahan pada setiap wilayah agar informasi yang ditampilkan nanti lebih detail dan diharapkan nantinyadapat dikembangkan lagi menggunakan metode Fuzzy C-Means.

\section{DAFTAR PUSTAKA}

[1] BNN, 2019, Penggunaan Narkotika di Kalangan Remaja Meningkat: BNN

[2] Bobby Poerwanto, Riska Yanu Fa'rifah, 2019, Algoritma K-Means Dalam mengelompokkan Kecamatan Di Tana Luwu Berdasarkan Produktifitas Hasil Pertanian. Jurnal Ilmiah d'Computare Volume 9 Edisi Januari 2019

[3] Fina Nasari, Charles Jhony Manto Sianturi, 2016, Penerapan Algoritma K-Means Clustering Untuk Pengelompokan Penyebaran Diare Di Kabupaten Langkat. Cogito Smart Jurnal Volume 2, No.2 Desember 2016

\section{KESIMPULAN DAN SARAN}

\subsection{Kesimpulan}

Berdasarkan hasil implementasi dari perancangan aplikasi pemantauan wilayah persebaran pasien pasca rehabilitasi narkoba di Malang berbasis web, beberapa pengujian telah dilakukan maka didapatkan kesimpulan :

1. Penerapan metode K-means Clustering untuk aplikasi pemantauan wilayah pasien pasca rehabilitasi narkoba di Malang berhasil diterapkan kedalam sistem, sehingga sistem dapat mengelompokkan wilayah perkecamatan berdasarkan tingkat penangananya.

2. Hasil clustering menggunakan K-means menghasilkan 3 cluster dengan intensitas wilayah yaitu cluster 1 dengan intensitas banyak berjumlah 1 kecamatan, cluster 2 dengan intensitas sedang berjumlah 5 kecamatan dan cluster 3 dengan intensitas sedikit berjumlah 12 kecamatan.

3. Hasil pengujian performansi sistem membandingkan pengelompokan manual dengan pengelompokan pada sistem untuk menunjukkan tingkat akurasi $100 \%$ pengelompokan pada wilayah pasien pasca rehabilitasi narkoba perkecamatan di Malang, sedangkan untuk pengujian user menunjukkan hasil sangat setuju $87.5 \%$ dan setuju $12.5 \%$ dari 2 pengguna aplikasi yaitu admin BNN Kota Malang.

\subsection{Saran}

Untuk mengembangan aplikasi yang lebih baik, ada beberapa saran untuk aplikasi pemantauan wilayah persebaran pasien pasca rehabilitasi yaitu, pada

[4] Gading Sadewo Mhd, A. A, 2018. Penerapan Algoritma Clustering Dalam Mengelompokan Banyaknya Desa/Kelurahan Menurut Upaya Antisipasi/Mitigasi Bencana Alam Menurut Provinsi Dengan K-Means. Jurnal KOMIK (Konferensi Nasional Teknologi Informasi dan Komputer) Volume 2, No.1 Desember 2018.

[5] Mardani. H. 2008, Penyalahgunaan Narkoba Dalam Perspektif Hukum Islam Dan Hukum Pidana Nasional, Jakarta, PT. Raja Grafindo Persada

[6] Muh. Fahrisyal Saputra, Muhammad Sadly Said, 2016, Sistem Informasi Geografis Persebaran Lembaga Pendidikan Di Kota Kendari berbasis Web. Vol. 1, No. 2

[7] Putu Kurniawan Adi Krisna, I. P. 2014, Sistem Informasi Geografis Pemetaan Penyebaran Penyakit Berbasis Web. Jurnal MERPATI Vol. 2, No. 3, Desember 2014

[8] Septian Wulandari. 2020, Clustering Kecamatan Di Kota Bandung Berdasarkan Indikator Jumlah Penduduk Dengan Menggunakan Algoritma KMeans. Jurnal Seminar Nasional Riset dan Teknologi (SEMNAS RISTEK) Jakarta, 27 Januarin2020

[9] Yolanda, Dania Puteri. Peran Pekerja Sosial Dalam Rehabilitasi Korban Human Trafficking di Rumah Perlindungan Sosial Anak Bambu Apus Jakarta Timur. Diss. FISIP UNPAS, 2016

[10] Yudi Agusta, 2007, K-Means - Penerapan, Permasalahan dan Metode Terkait. Jurnal Sistem dan Informatika, Vol. 3, 47-6 